\title{
Spatial analysis of asbestos exposure and occupational health care in Poland during the period 2004-2013
}

\author{
Małgorzata Krówczyńska, Ewa Wilk \\ Department of Geoinformatics, Cartography and Remote Sensing, Faculty of Geography and Regional \\ Studies, University of Warsaw, Warsaw, Poland
}

\begin{abstract}
Asbestos is carcinogenic to humans and exposure to this substance can cause a wide range of diseases. In Poland 1997, a statutory ban was introduced on the production, use and marketing of products containing asbestos. The National Programme for Asbestos Abatement for 2009-2032 includes scheduled activities considering asbestos exposure assessment and health protection. As there are several data sources for asbestos exposure in Poland, which are not linked, the aim of this study was to gather and order them developing a PostgreSQL database, an open-source, objectrelational system. The data gathered combines the following information: the quantity of asbestos-cement products in use, details of asbestos manufacturing plants, the results of the measurements of asbestos fibre concentrations in the air and cases of asbestos-related diseases. The relational database was then used to develop a spatial analysis of asbestos monitoring and exposure in Poland to demonstrate the current state of realisation of the National Asbestos Abatement Programme in the country for 2009-2032 with the use of geoinformation techniques. The use of a database
\end{abstract}

Correspondence: Małgorzata Krówczyńska, Department of Geoinformatics, Cartography and Remote Sensing, Faculty of Geography and Regional Studies, University of Warsaw, Krakowskie Przedmiescie 30, 00-927 Warsaw, Poland.

Tel: +48.22.5520654 - Fax: +48.22.5521521.

E-mail: mkrowczynska@uw.edu.pl

Key words: Asbestos exposure; Geographic Information System; Spatial analysis; Asbestos health effects database; Poland.

Contributions: the authors contributed equally.

Conflict of interest: the authors declare no potential conflict of interest.

Funding: none.

Received for publication: 6 March 2018.

Revision received: 20 August 2018.

Accepted for publication: 21 August 2018.

(C) Copyright M. Krówczyńska and E. Wilk, 2018

Licensee PAGEPress, Italy

Geospatial Health 2018; 13:689

doi:10.4081/gh.2018.689

This article is distributed under the terms of the Creative Commons Attribution Noncommercial License (CC BY-NC 4.0) which permits any noncommercial use, distribution, and reproduction in any medium, provided the original author(s) and source are credited. on health aspects of occupational and environmental asbestos exposure was also proposed in Asbestos, Asbestosis, and Cancer: Helsinki Criteria update 2014.

\section{Introduction}

Asbestos refers to a group of naturally occurring fibrous serpentine or amphibole minerals: chrysotile, amosite, crocidolite, tremolite, anthophyllite and actinolite (Ross et al., 2008). Asbestos fibres have a high tensile strength, are resistant to thermal and chemical degradation, flexible, have a high electrical resistance and can be woven (Hendry, 1965; Ross et al., 2008). This unique set of physical and chemical properties has led to many industrial applications of asbestos worldwide (Virta, 2003; Wilk et al., 2014). The global peak of production of asbestos-containing products was in the 1960 s and 1970 s, when there were more than 3,000 applications in the national economy (Virta, 2003). The main use of chrysotile was in the asbestos cement industry, which mostly produced roof coverings, pressure pipes and floors but also textiles, rope, cord, yarn, paper, friction and composite materials, and other household products (Wilk et al., 2014). Crocidolite was also mainly used in the manufacture of asbestos cement products (Thompson and Mason, 2002), as well as in the manufacture of acid-resistant filters, packaging, insulation and certain types of lagging. Tremolite and actinolite are of less importance from an economic point of view; they were exploited in the chemical industry as filter mediums and also for other needs in the field of filtration. Anthophyllite was used in the chemical industry as a filler in the rubber and plastic industries, and in various adhesives and cements. The use of amosite was important for insulation in the manufacture of pipes and boilers (Hendry, 1965). Asbestos cement roofing accounts for about $90 \%$ of all asbestos-containing materials produced and used around the world (Collegium Ramazzini, 2010). In Poland, asbestos-containing products were manufactured from raw materials imported from the former Soviet Union (Russia, Lithuania, Kazakhstan and Belarus), Canada, Italy, Australia and the UK. Over $90 \%$ of all asbestos used in production was chrysotile; less than $10 \%$ was crocidolite and amosite, which were used until the 1980s in the manufacturing process of pressure pipes (Dyczek, 2006).

The negative effects of asbestos and asbestiform fibres on human health are a consequence of inhalation of fibres, such fluoro-edenite fibres, eronite mineral fibres and tremolite mineral fibres when present in the air (Ledda et al., 2018). The International Agency for Research on Cancer stated that minerals containing asbestos in any form should be regarded as carcinogenic to humans (IARC, 2012). The number of cases of asbestosrelated diseases depends on the type of asbestos used and increas- 
es with the use of crocidolite in production (McDonald and McDonald, 1978). The incidence of lung cancer and malignant mesothelioma is closely correlated to the concentration of asbestos fibres in the air. It is influenced by the number and condition of asbestos-containing products used and the level of environmental pollution (Carbone and Bedrossian, 2006). Owing to the pathogenic nature of asbestos, a statutory ban on the production, use and marketing of products containing asbestos was introduced in Poland in 1997. A similar ban was implemented in the EU in 2005 (the Commission Directive 1999/77/EC of July 26, 1999). Member States were encouraged to prepare strategies for national asbestos removal programmes (Directive 2009/148/EC).

In the National Programme for Asbestos Abatement in Poland for 2009-2032 (Ministry of Economy, 2010). Ministry of Economy activities for the assessment of asbestos exposure and health protection were scheduled with detailed measures regarding health protection (Krówczyńska et al., 2014). Monitoring the morbidity and mortality rates of asbestos-related diseases is a substantial task in human health protection and asbestos exposure (Corfiati et al., 2015). Carlin et al. (2015) stressed that only a multidisciplinary approach connecting the different sources of data on asbestos could lead to an improved understanding of fibre-induced illnesses and new risk assessment strategies to protect affected communities.

The purpose of this study was to collect, organize and assess the completeness and the quality of data gathered by the institutions involved in the examination of workers employed in asbestos manufacturing plants. The basis for the design and development of the spatial analysis was the development of the PostreSQL database on asbestos occupational diseases in relation to the quantity of asbestos-containing products currently used, the results of the measurements of the asbestos fibres concentrations in the air and the location of former asbestos manufacturing plants and laboratories, which conducted the measurements of asbestos fibre concentrations in the air. An additional objective was to evaluate the data and report back for a larger study involving the monitoring of environmental asbestos exposure and geo-referenced time activity patterns in terms of asbestos-related diseases in Poland. To the best of the authors' knowledge, this case study is the first reportback assessment based on the use of spatial analysis of asbestos exposure in Poland involving different sources of data. We aimed to provide a new framework for the detection of asbestos-related diseases in Poland and the study constitutes a contribution to more extensive research to determine the effects of occupational and environmental exposure on asbestos-related disease in Poland in order to achieve the targets set in the National Asbestos Abatement Program in Poland for 2009-2032.

The period 2004-2013 was chosen because 2004 was the year when action was taken with regard to asbestos fibres concentration in the air, and measurements started to be carried out in all communes.

\section{Materials and Methods}

\section{Data sources}

The amount of asbestos-cement products in use was derived from the Asbestos Database, which is a legal tool for the inventory of asbestos products in Poland (Asbestos Database, 2014). In the period of 2004-2013 measurements of asbestos fibre concentrations in the air, including the date of measurement, the number of measurements and the concentration of asbestos fibres, was carried out at the request of the Minister of Economy (SzeszeniaDąbrowska and Sobala, 2008; Szeszenia-Dąbrowska and Sobala, 2010). The results constituted the input data for the database to be developed and special attention was paid to particular communes. They were digitalised and constituted one of the interconnected tables in the database developed during this study. As there were 28 asbestos-manufacturing plants operating in Poland; the location of these plants, the types of asbestos used and the kinds of asbestos-containing products fabricated were gathered for the database. This work was executed by use of a field survey and indepth interviews (Wilk et al., 2014). The survey allowed the arrangement, ordering, preparation and description of the asbestosmanufacturing plants. The gathered data were then supported by information on the incidence of asbestos-related diseases derived from the Amiantus Program (Szubert et al., 2011) and the National Neoplasm Register (Wojciechowska and Didkowska, 2016). The collected data refer to the period of 2004-2013 and are classified per county and commune. The current three-tier administrative division of Poland has been in force since January 1, 1999. The first degree units are the 16 provinces, the second degree units refer to the 380 counties, and the third degree units are the 2,478 communes, including 302 municipal, 628 urban-rural and 1,548 rural communes. The calculations were performed for the general population. The information on the territorial division of the country was acquired from the Polish National Geodetic and Cartographic Documentation Centre (Państwowy Rejestr Granic, 2017).

\section{The database}

In order to allow future collection of data as well as to ensure the possibility of searching and analysing the collected data, a database adapted to the requirements of the PostgreSQL database was designed and developed (Singh et al., 2012). The PostgreSQL database structure is an open-source, object-relational system that complies with the requirements of the Electronic Spatial Information System. It was used for monitoring the asbestos removal process and products containing asbestos (GeoAzbest) in the Asbestos Database (Krówczyńska et al., 2014). All data, which were acquired during the survey undertaken, were organized and collected in the developed PostreSQL relational database. This database consists of a number of linked tables with the following data: i) Communes: a list of all communes in Poland in compliance with the National Official Register of the Territorial Division of the Country (TERYT) and in accordance with the Asbestos Database; ii) Counties: a list of all counties in accordance with the state register; iii) Provinces: a list of all provinces in Poland consistent with the state register; iv) Concentrations: a detailed list of the measured concentrations of asbestos fibres in relation to particular communes; v) Asbestos-manufacturing plants: a detailed summary of all plants using asbestos in their manufacturing process; vi) Provincial Occupational Medicine Centres: a list of all such centres carrying out asbestos-related disease research among employees of asbestos manufacturing plants; vii) Diseases: data on asbestos-related diseases diagnosed among plant employees in particular years; and viii) Laboratories: data on research laboratories with the accreditation for the collection of air samples for the determination of the concentration of asbestos fibres.

The Diseases table contains more detailed data on the inci- 
dence of the occupational asbestos-related diseases, such as: i) the total number of patients examined in a given period; ii) the average number of years they worked in the asbestos-manufacturing plant; iii) number of patients who smoke cigarettes; iv) the total number of patients diagnosed with asbestos-related diseases; $v$ ) the number of patients diagnosed as having asbestos pneumoconiosis; vi) the number of patients diagnosed with chronic bronchitis; vii) number of patients diagnosed with bronchial asthma; viii) the number of patients diagnosed with emphysema; ix) the number of patients diagnosed with lung cancer; $x$ ) the number of patients diagnosed with pulmonary tuberculosis; $x i)$ the number of patients with pleural mesothelioma; xii) the number of patients with other asbestosrelated diseases; xiii) the number of patients referred to sanatorium for treatment; and xiv) the number of patients who died as a result of asbestos-related diseases.

All data gathered in the individual tables were linked to each other on the basis of appropriate identifiers that constituted a relational database, designed in PostgreSQL. The database structure was developed to ensure full compliance with the Asbestos Database that currently stores the information on asbestos-containing products in Poland (Krówczyńska and Wilk, 2016). ArcGIS software, version 10.5 (ArcGIS, ESRI, Redlands, CA, USA) was used for mapping on the basis of the developed PostgreSQL database.

\section{Results}

The quantity of asbestos-cement products in Poland amounts to approximately 14.5 million tons as recorded in the National Abatement Programme, but only 5.2 million tons were recorded in the Asbestos Database (Table 1). The discrepancy is due to the fact that not all products estimated to be around were entered into the Asbestos Database, mainly becuse much of it were supposed to have been disposed before 2004. However, it should be admitted that there is no documentation of this.

These products are mainly asbestos-cement products used for roof covering, façade claddings and water pipes (Wilk et al., 2014). In the aforementioned programme, there were regulations implemented that considered the concentration of asbestos fibres in the air. Based on the information gathered in the PostreSQL database, the results of the measurements of the concentration of asbestos fibres in the air performed in 2004-2013 were presented using spatial analyses. The areas of measurement of concentration
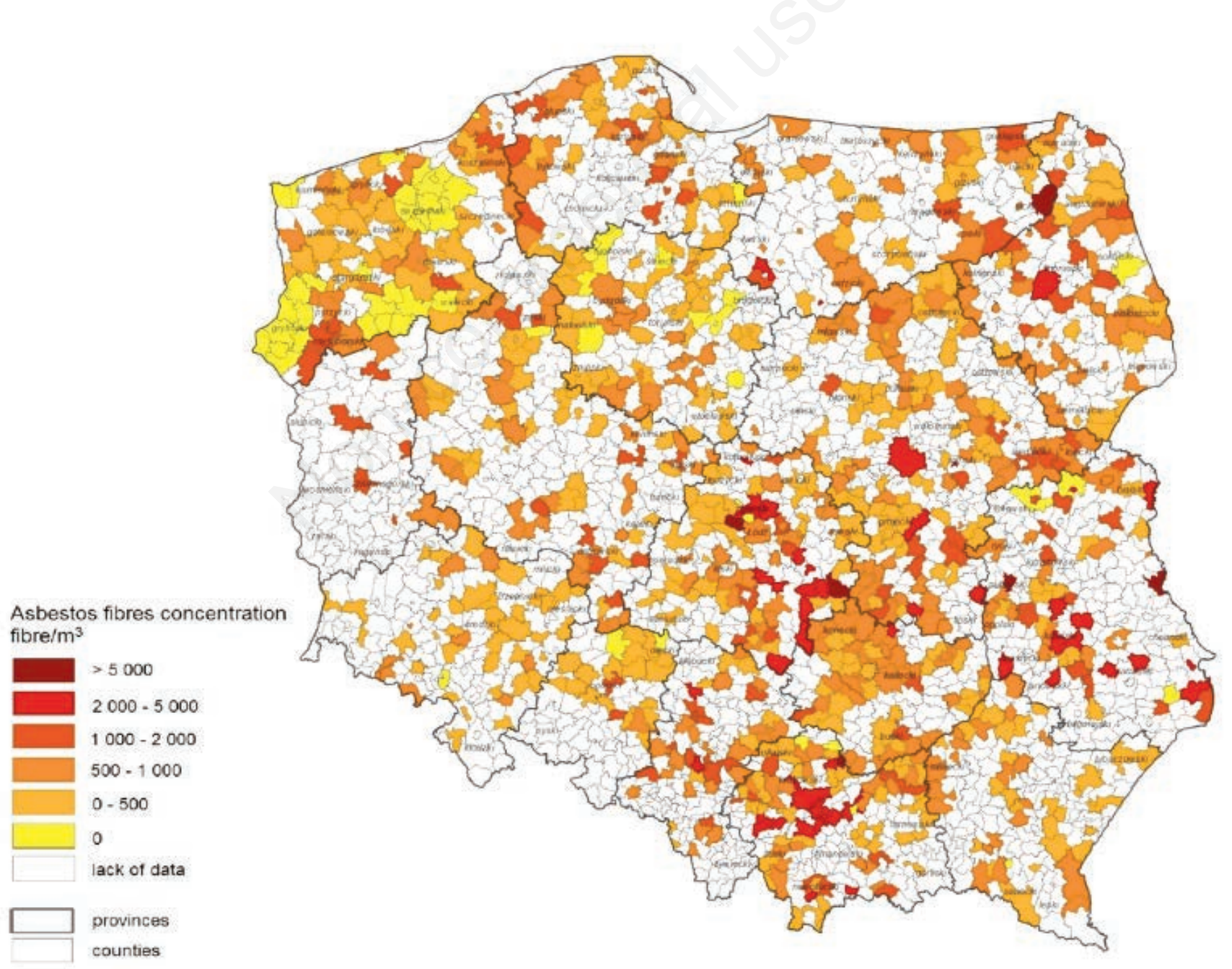

Figure 1. Average concentration of asbestos fibres at the commune level in the period 2004-2013. 
Table 1. Amounts of asbestos-cement products presumed to be in use, populations at risk and the average concentration of asbestos fibres present in the air by province.

\begin{tabular}{lccc} 
Province & $\begin{array}{c}\text { Amount of asbestos-cement } \\
\text { products (tons) }\end{array}$ & $\begin{array}{c}\text { Population } \\
\text { (number of people) }\end{array}$ & $\begin{array}{c}\text { Average concentration of } \\
\text { asbestos fibres } \\
\text { (per m }\end{array}$ \\
Dolno l skie & 114,198 & 445 \\
Kujawsko-pomorskie & 375,490 & $2,915,241$ & 65 \\
\hline Lubelskie & 850,436 & $2,097,635$ & 1,991 \\
Lubuskie & 65,171 & $2,175,700$ & 0 \\
\hline Łódzkie & 531,553 & $1,022,843$ & 621 \\
Małopolskie & 286,771 & $2,538,677$ & 857 \\
\hline Mazowieckie & $1,040,811$ & $3,337,471$ & 1,298 \\
Opolskie & 61,936 & $5,268,660$ & 47 \\
\hline Podkarpackie & 245,378 & $1,016,212$ & 991 \\
Podlaskie & 404,172 & $2,127,286$ & 985 \\
\hline Pomorskie & 166,753 & $1,202,365$ & 689 \\
lskie & 239,193 & $2,276,174$ & 613 \\
\hline wi tokrzyskie & 378,583 & $4,630,366$ & 793 \\
Warmi sko-mazurskie & 165,013 & $1,280,721$ & 1,118 \\
\hline Wielkopolskie & 511,729 & $1,452,147$ & 86 \\
Zachodniopomorskie & 110,603 & $3,447,441$ & 161 \\
\hline
\end{tabular}

Asbestos fibres concentration fibre/m $\mathrm{m}^{3}$

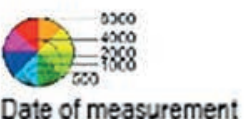

\begin{tabular}{|l|l|}
\hline 2004 \\
$2004-2005$ \\
\hline 2005 \\
2006 \\
2007 \\
2010 \\
2012 \\
2013 \\
\hline
\end{tabular}

Amount of asbostos-

cement products [Mg]

provinces counties

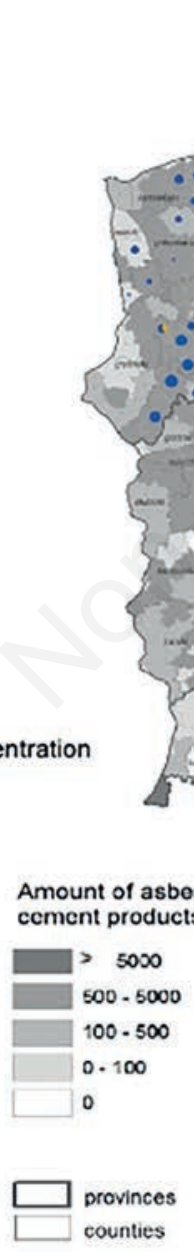

Figure 2. Annual, average concentrations of asbestos fibres in communes in the period 2004-2013 in relation to the amount of asbestoscement products in use. 
of asbestos fibres in the air were presented at the commune level (Figure 1).

The measurements of the concentration of asbestos fibres in the air were made in 1,037 communes, which constitute $45.9 \%$ of the total number of communes in the administrative division of Poland. The highest number of communes included in concentration measurements was in the provinces Mazowieckie (153), Zachodniopomorskie (98), Świętokrzyskie (83), Małopolskie (138), Lubelskie (118) and Łódzkie 117. With regard to the number of communes in the provinces, the highest percentage of communes was examined in Zachodniopomorskie (87\%), in Świętokrzyskie (81\%) and in Małopolskie (76\%). It is worth noting that in the Lubuskie measurements of the concentration of asbestos fibres in the air were not taken, while in Dolnośląskie the measurements covered only $10.7 \%$ of the communes.

When analysing the average concentration of asbestos fibres in particular provinces, it can be observed that three communes in Lubelskie, three communes in Lodzkie, one commune in Małopolskie, one commune in Warmińsko-Mazurskie and one commune in Mazowieckie recorded concentrations above 5,000 fibres per cubic metre. In 2004, concentrations in excess of 5,000 fibres per cubic metre were noted in seven communes, while in 2005 and in 2013 this level was only noted in one. The highest average concentration found in the years 2004--2005 was 8,229 fibres per cubic metre and this was measured in 2004 in the commune of Annopol in Lubelskie Province.

The cartographic presentation of the measurements of the concentration of asbestos fibres in the air against the amount of asbestos-containing products was particularly useful for the analysis of the phenomenon of exposure and of health protection against the harmful effects of asbestos (Figure 2).

The correlation coefficient for the concentration of asbestos fibres per cubic metre compared to the average amount of asbestos-cement products in use amounted to 0.54. If three provinces were excluded from the analysis: i.e. Lubuskie, due to the lack of measurements of the concentration of asbestos fibres in the air and Kujawsko-Pomorskie and Zachodniopomorskie, for which the measurements in all analysed communes were below the threshold, the correlation coefficient would increase to 0.65 . An additional analysis was performed showing the results of the con-

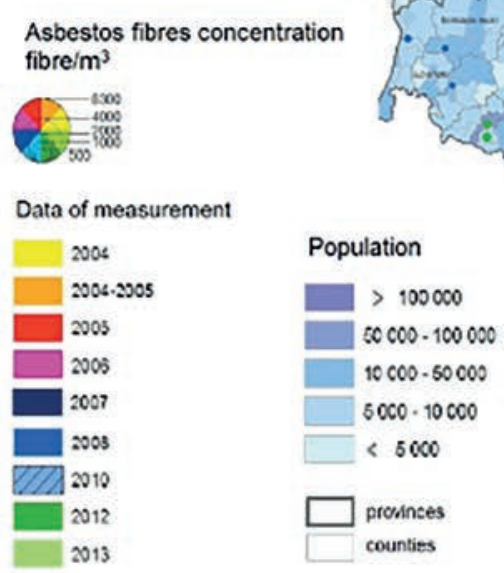

Figure 3. Annual, average concentrations of asbestos fibres in communes in the period 2004-2013 in relation to their level of population. 
centration of asbestos fibres in the air in relation to the population of the communes (Figure 3). In five provinces, the average asbestos fibre concentration in the air was about 1,000 fibres per cubic metre, which signifies an clearly harmful impact of asbestos fibres on more than 12 million people.

The survey undertaken also covered the number of asbestosrelated disease cases reported in 2004-2013 in relation to the manufacturing plants that used asbestos in production (Figure 4).

The number of reported cases for the period 2000-2010 is compared to the annual numbers for the following years.

The highest number of reported cases of asbestos-related diseases among asbestos workers was noted in Lublin (559 cases); 554 patients were diagnosed with asbestosis, four with lung cancer and one with pleural mesothelioma. An equally high level of reported diseases were recorded in Wierzbica, a village in Radom County. There were 452 cases of asbestosis, 15 cases of lung cancer and five cases of pleural mesothelioma, which in total accounts for 472 cases of diagnosed asbestos-related diseases. At the plant in Szczucin, where crocidolite was used in the production of pressure pipes, the highest rate of pleural mesothelioma was recorded (15 cases).

Figure 5 shows the comparison of the number of people examined and the number of cases of diagnosed diseases found in asbestos manufacturing plants. Among the population of examined patients, 2,654 cases of asbestosis, 84 cases of lung cancer and 50 cases of pleural mesothelioma were diagnosed, which means that $22.5 \%$ of patients were diagnosed with asbestosis, $0.7 \%$ with lung cancer and $0.4 \%$ with pleural mesothelioma. The highest percentage of asbestosis cases was observed in the provinces Lubelskie and Małopolskie. In Pomorskie Province, however, no cases were diagnosed. On 4 August, 2004 the Ordinance of the Minister of Health ordered the Provincial Occupational Medical Centres to conduct periodic medical examinations on employees in plants that used asbestos in production. There are 13 local medicine centres capable of providing support to workers in asbestos manufacturing plants (Figure 6).

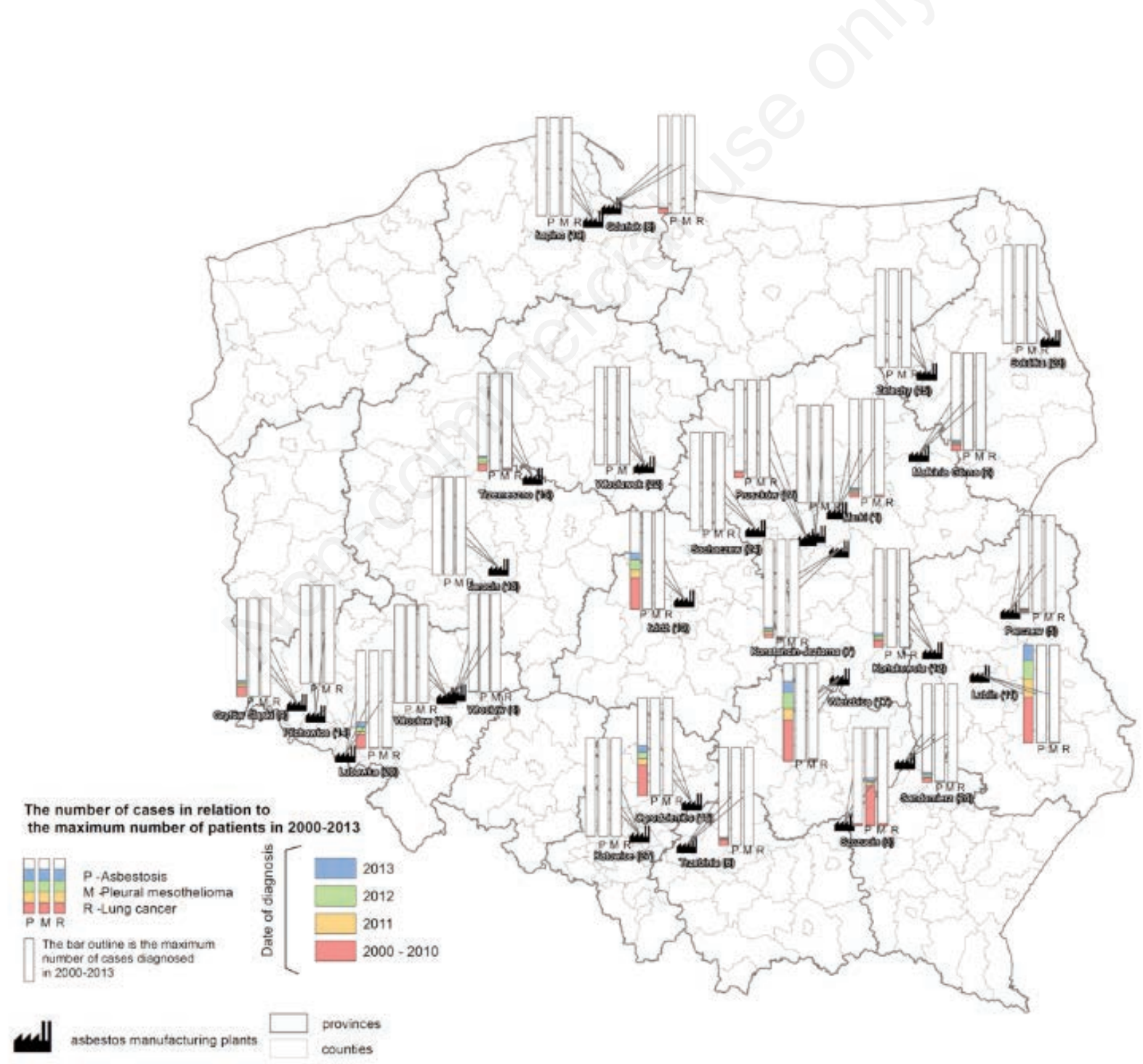

Figure 4. The number of reported cases of asbestos-related diseases in the period 2004-2013 in relation to the localisation of the asbestos manufacturing plants. 


\section{Discussion}

Asbestos has found application in many areas of industry and the economy, owing to the unique properties of asbestos fibres (Virta, 2003). The harmful effect of the inhalation of asbestos and asbestiform fibres is a serious public health problem. Research on the occupational exposure and the effects of exposure to asbestos dust is the subject of much research work (McCambridge et al., 2018). Epidemiological studies considering environmental exposure are less frequently undertaken (Harper et al., 2015). For this study, data was gathered on all activities undertaken in Poland with regard to employees working in asbestos manufacturing plants. In addition to collecting the data, the information was ordered, analysed and presented with the use of maps and spatial analysis. This may lead to a description of the environmental exposure, for example the quantity and distribution of asbestos-cement products in use in Poland and the concentration of asbestos fibres in the air. All data has been collected at the commune level (the smallest territorial unit in the country). According to the division proposed by Wakefield (2007), the disease should be screened in relation to occupational exposure, which is the starting point for determining the spatial regression to assess potential risk factors in relation to occupational and environmental exposure. This means analysing the spatial health diversity of the population in terms of environmental factors. An important element is the visualization of the distribution of a given disease in order to link detected cases of disease with possible risk factors (Saib et al., 2014). These studies form the basis for work to determine the impact of environmental exposure and to determine the health effects of this exposure.

It is worth noting that Poland is one of the countries where the reported detection of asbestos-related diseases is one of the lowest in Europe (Bianchi and Bianchi, 2014). In Poland, compared to other European countries using similar amounts of asbestos per capita, approximately 3-4 times fewer cases of asbestos-related diseases are diagnosed (Marinaccio et al., 2005). It can therefore be presumed that the number of asbestos-related are underestimated, especially in areas of asbestos environmental exposure. Based on the results of the research undertaken, this hypothesis is verified when the number of diagnosed cases of asbestos-related diseases detected among workers from asbestos-manufacturing plants is compared to all other cases. Considering the fact that the use of asbestos-containing products is still allowed in Poland, and will be until the end of 2032, the incidence of asbestos-related diseases will continue as there will still be exposure to asbestos.

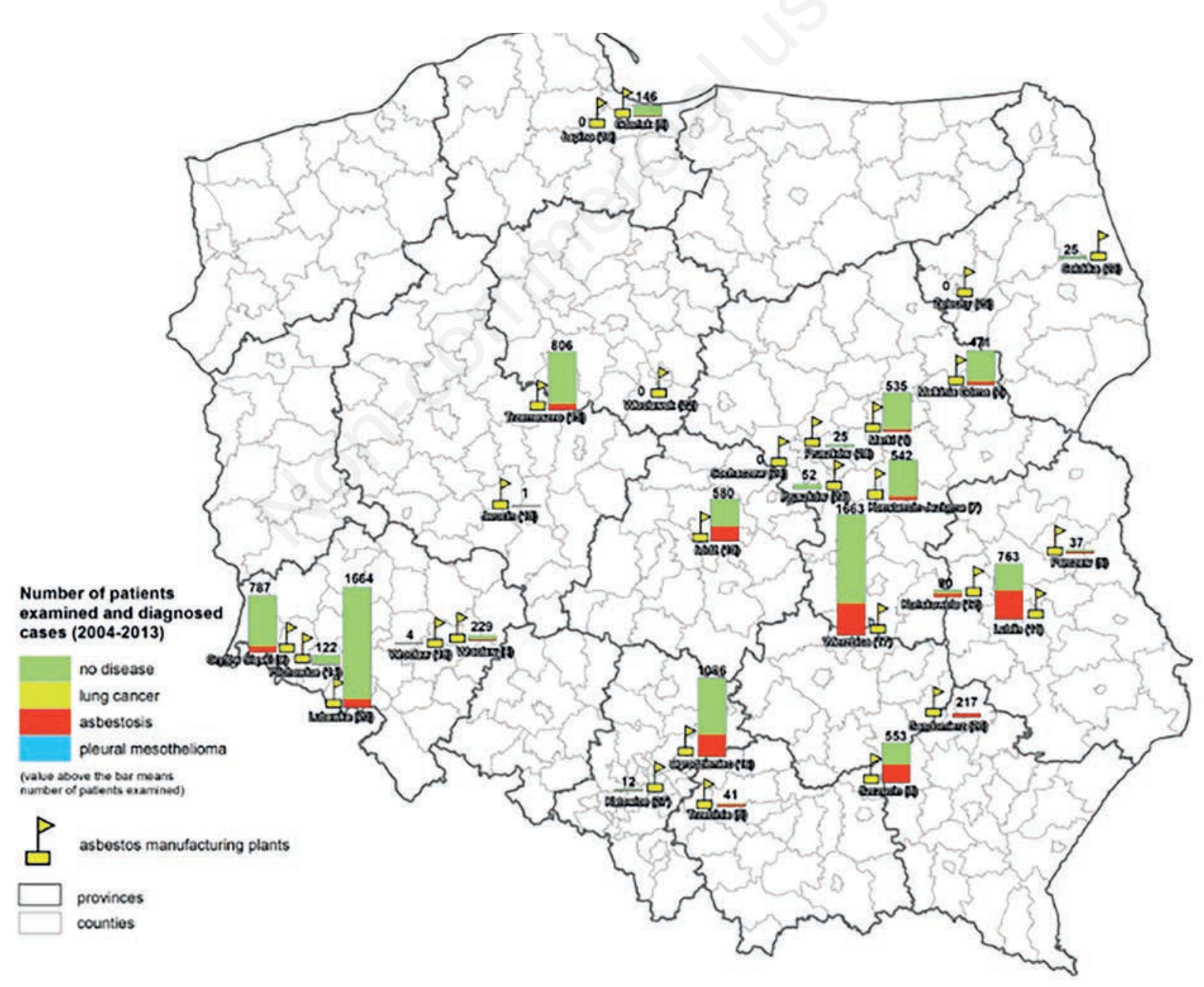

Figure 5. Comparison of the number of patients examined and the number of cases of diagnosed occupational diseases among workers at the asbestos manufactoring plants in Poland. 
In all industrialized countries in which preventive scientific programmes are undertaken, the results obtained form the basis for assessing the prevailing public health situation and epidemiological estimates as well as the basis for the organization of disease prevention and health care (Goldberg et al., 2006; Marinaccio and Nesti, 2003). Therefore, it is important to conduct research aimed at increasing the detection of asbestos-related diseases, including mesothelioma. As early as 1996, Szeszenia-Dąbrowska et al. emphasized that there was no epidemiological research in Poland, which makes it impossible to verify hypotheses related to the incidence of this type of cancer. In order to develop a strategy aimed at reducing the extent of the environmental asbestos exposure, it is necessary to undertake epidemiological research (Świątkowska, 2009). Malignant neoplasms are the second most common cause of death in Poland, constituting $27 \%$ of all deaths among men and $24 \%$ of deaths among women (Central Statistical Office, 2015). Since 1999, the number of deaths in Poland has increased by $23 \%$, while the effectiveness of oncological treatment is lower than in the majority EU countries, one of the reasons being delays in providing the diagnosis (NIK, 2018). An important part of the needs assessment for health services is the identification of areas of potential clusters with a high risk of disease incidence, because understanding the characteristics of high-risk areas may indicate the need to improve health care in that area or for that particular sector of the population (Osei and Duker, 2008). An attempt to monitor the activities implemented by the National Asbestos Abatement Programme for 2009-2032 could constitute the beginning of the delimitation of high-risk areas based on the available data, such as the concentration of asbestos fibres in the air (Figure 1 ), the amount of products in use (Figure 2) and the number of cases of asbestos-related diseases.

The degradation process of products containing asbestos that have been present in the environment for years, support the expectation that the number of cases related to asbestos-dependent diseases will increase. Safe use of the products has been established for 30 years, and the latency period of asbestos-related diseases is from 20 to 50 years (Szeszenia-Dąbrowska and Świątkowska, 2016). Secondly, degradation may also be related to air pollution (Dockery, 1993). It is estimated that in Western Europe, in the next 25 years, half a million people will die due to diseases caused by exposure to asbestos dust (World Health Organization, 2015). Owing to the growing number of cases, currently environmental exposure to asbestos fibres is the most important medical issue to address in in Poland.

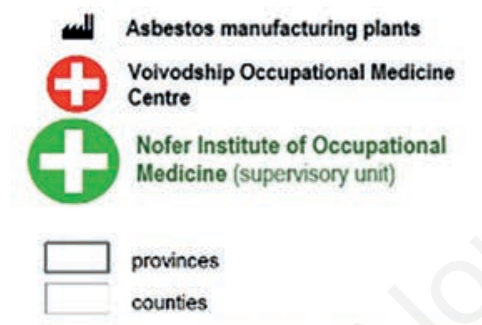

Provincial Occupational Medicine Centre (WOMP)

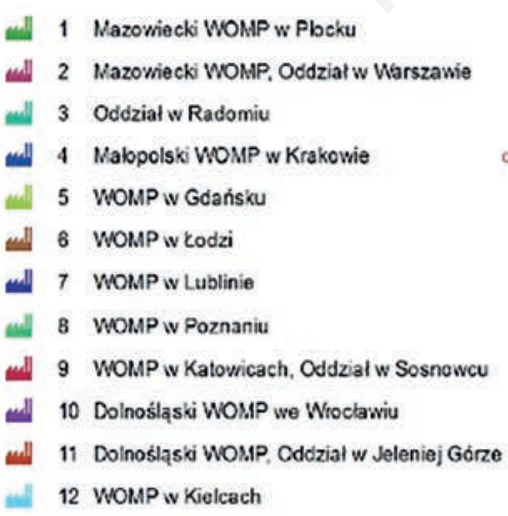

13 Podlaski WoMP w Bialymstoku

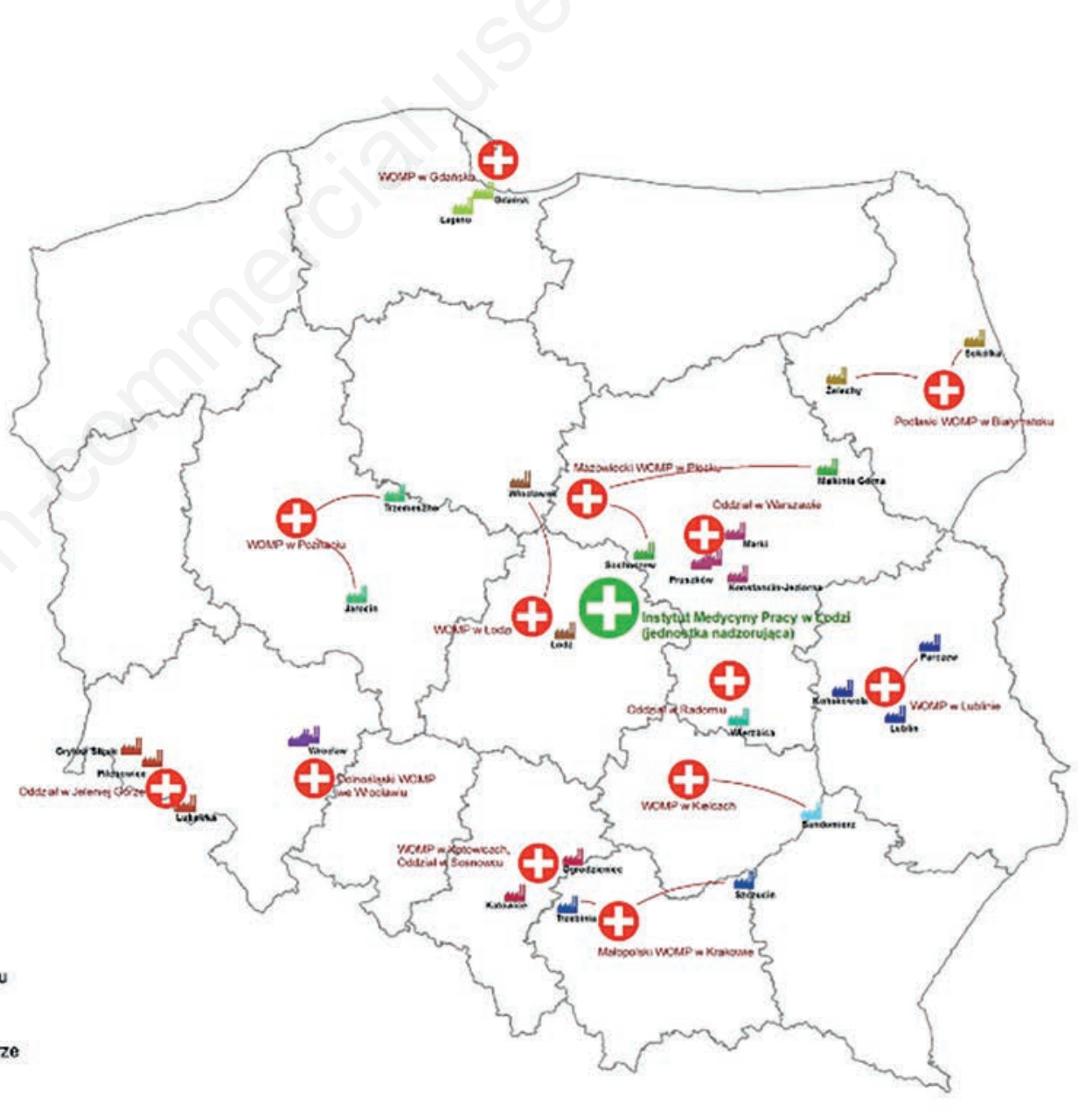

Figure 6. The range of operation of the Provincial Occupational Medicine Centres in relation to the plants that used asbestos in their production. 
The developed database, assuming it is updated on a regular basis, may constitute a part of the Electronic Spatial Information System to monitor the implementation of the Polish National Asbestos Abatement Programme for 2009-2032 (Krówczyńska et al., 2014). The development and use of a database on the health aspects of occupational and environmental exposure was also proposed in the report Asbestos, Asbestosis, and Cancer: Helsinki Criteria update 2014 (Oksa et al., 2014). This update summarized the current knowledge on the methods of management and elimination of asbestos-related diseases and it was recommended that new data and research were used for the diagnosis and determination of best practices in the detection of asbestos-related diseases. In the general remarks provided on the guidelines for the identification of asbestos, it was noted that people exposed to asbestosrelated diseases should be identified on the basis of an environmental interview. The 2014 Helsinki Criteria update focused on screening for the diagnosis of asbestos-related lung cancer and the observation of workers exposed to asbestos, as well as the diagnosis of asbestosis and asbestos-related diseases (pathology and biomarkers). For this purpose, it seems legitimate to maintain an ordered database or register, in particular with reference to the geographically connected data. As there is new data available on the amount of asbestos-cement products in use in Poland (Wilk et al., 2017), it would be desirable to continue research on the complexity of guiding activities in the field of elimination of asbestos-related diseases, as well as appropriately planning both the measurements of asbestos fibre concentrations and pro-health activities dedicated to residents of communes in which the largest amounts of asbestoscontaining products are used. If for any reason asbestos fibre concentration testing activities are not continued, it is possible to develop a statistical model on the concentration of asbestos fibre in the air in relation to the quantity and the deterioration status of asbestos-cement products and this could be updated using the annual frequency found in the Asbestos Database.

\section{Conclusions}

The survey undertaken aimed to prepare a relational database to develop spatial analysis presenting the actions taken in the areas of exposure and health protection, which have been implemented as part of the National Asbestos Abatement Programme in Poland, in 2004-2013. There is no system in Poland in which all data on the health aspects on asbestos-related diseases and monitoring, collected by different institutions, are summarized, gathered and analysed. Therefore, the essence of the research was the development of a uniform and coherent database, allowing the preparation of geoinformatic analyses. It is a positive sign that, as a continuation of the undertaken research, the database will be expanded to include data from the National Cancer Registry on the number of deaths and cases of mesothelioma and lung cancer associated with environmental exposure in order to identify the areas of higher risk of asbestos-related disease. The developed database and spatial analysis is crucial for the development of the National Programme for the Elimination of Asbestos-Related Diseases, as recommended by the World Health Organisation and International Labour Organisation (2007) as a consensus policy document that outlines the magnitude of the problem and strategies for the elimination of asbestos-related diseases, defining long-term objectives and an institutional framework for action, and to provide directions for raising awareness and capacity building.

\section{References}

ArcGis 10.5. Available from: http://www.esri.com/en/arcgis/products/arcgis-pro/overview

Asbestos Database, 2014. Available from: https://www.bazaazbestowa.gov.pl/pl/

Bianchi C, Bianchi T, 2014. Global mesothelioma epidemic: Trend and features. Indian J Occup Environ Med 18:82-8.

Carbone M, Bedrossian CW, 2006. The pathogenesis of mesothelioma. Semin Diagn Pathol 23:56-60.

Carlin DJ, Larson TC, Pfau JC, Gavett SH, Shukla A, Miller A, Hines R, 2015. Current Research and Opportunities to Address Environmental Exposures. Environ Health Perspect 123:1947.

Central Statistical Office, 2015. Available from: www.stat.gov.pl

Collegium Ramazzini, 2010. Asbestos is still with us: repeat call for a universal ban. Odontology 98:97-101.

Commission Directive 1999/77/EC of 26 July 1999 adapting to technical progress for the sixth time Annex I to Council Directive 76/769/EEC on the approximation of the laws, regulations and administrative provisions of the Member States relating to restrictions on the marketing and use of certain dangerous substances and preparations (asbestos), 1999. Available from: hhttp://eur-lex.europa.eu/legal-content/EN/TXT/?uri= CELEX:31999L0077

Corfiati M, Scarselli A, Binazzi A, Di Mazrio D, Verardo M, Mirabelli D, Gennaro V, Mensi C, Schallemberg G, Merler E, Negro C, Romanelli A, Chellini E, Silvestri S, Cocchioni M, Pascucci C, Stracci F, Romeo E, Trafficant L, Angelilli I, Menegozzo S, Musti M, Cavone D, Cauzilli G, Tallarigo F, Tumino R, Melis M, Iavicoli S, Marinaccio A, 2015. ReNaM Working Group. Epidemiological patterns of asbestos exposure and spatial clusters of incident cases of malignant mesothelioma from the Italian national registry. BMC Cancer $15: 286$.

Directive 2009/148/EC of the European Parliament and of the Council of 30 November 2009 on the protection of workers from the risks related to exposure to asbestos at work, 2009. OJ L 330, 28-36. Available from: http://eur-lex.europa.eu/legalcontent/en/TXT/?uri=CELEX:32009L0148

Dockery DW, Pope CA, Xu X, Spengler JD, Ware JH, Fay ME, Ferris BG Jr, Speizer FE, 1993. An association between air pollution and mortality in six U.S. Cities. New Engl J Med 329:1753-9.

Dyczek J, 2006. Surface of Asbestos-cement (AC) Roof Sheets and Assessment of the Risk of Asbestos Release. In: Proceedings of the International Seminar held in AGH on Asbestos Risk Reduction and Measurement of Asbestos Fibre Concentration. pp 57-63.

GeoAzbest. Available from: http://esip.bazaazbestowa.gov.pl Accessed: May 2017.

Goldberg M, Imbernon E, Rolland P, Gilg Soit Ilg A, Save M, de Quillacq A, Frenay C, Chamming S, Arveux P, Boutin C, Launoy G, Pairon JC, Astoul P, Galateau-Salle F, Brochard P, 2006. The French National Mesothelioma Surveillance Program. Occup Environ Med 63:390-5.

Harper M, Butler C, Berry D, Wroble J, 2015. Where occupation and environment overlap: US forest service worker exposure to libby amphibole fibers. J Occup Environ Hyg 12:D47-53.

Hendry N, 1965. The geology, occurrences, and major uses of asbestos. Ann NY Acad Sci 132:12-21. 
IARC, 2012. International Agency for Research on Cancer, Arsenic, Metals, Fibres and Dusts, Volume 100c, 2012. Available from: https://monographs.iarc.fr/wpcontent/uploads/2018/06/mono100C.pdf

Krówczyńska M, Wilk E, 2016. Geoazbest - web based service dedicated to monitoring of asbestos removal process. Roczniki Geomatyki 14,4:477-86.

Krówczyńska M, Wilk E, Zagajewski B, 2014. The Electronic Spatial Information System - tools for the monitoring of asbestos in Poland. Misc Geogr - Reg Stud Devel 18:59-64.

Ledda C, Senia P, Rapisarda V, 2018. Biomarkers for early diagnosis and prognosis of malignant pleural mesothelioma: The quest goes on. Cancers 10:203.

Marinaccio A, Montanaro F, Mastrantonio M, Uccelli R, Altavista P, Nesti M, Costantini AS, Gorini G, 2005. Predictions of mortality from pleural mesothelioma in Italy: a model based on asbestos consumption figures supports results from age-period-cohort models. Int J Cancer 115:142-7.

Marinaccio A, Nesti M, 2003. Regional operational centers, Analysis of survival of mesothelioma cases in the Italian registry (ReNaM). Eur J Cancer 39:1290-5.

McCambridge AJ, Napolitano A, Mansfield AS, Fennell DA, Sekido Y, Nowak AK, Reungwetwattana T, Mao W, Pass HI, Carbone M, Yang H, Peikert T, 2018. Progress in the Management of Malignant Pleural Mesothelioma in 2017. J Thorac Oncol 13:606-23.

McDonald AD, McDonald JC, 1978. Mesothelioma after crocidolite exposure during gas mask manufacture. Environ Res 17:340-6.

Ministry of Economy. Programme for Asbestos Abatement in Poland 2009-2032, 2010. Available from: http://www.mpit. gov.pl/media/15225/PROGRAM_ENG.pdf

NIK, 2018. Availability and effects of cancer treatment, the Supreme Audit Office, Warszawa. Available from: https://www.nik.gov.pl/plik/id,15932,vp,18449.pdf

Oksa P, Wolff H, Vehmas T, Pallasaho P, Frilander H, 2014. Asbestos, Asbestosis, and Cancer. Helsinki Criteria for Diagnosis and Attribution 2014. Helsinki, FN: Finnish Institute of Occupational Health.

Osei FB, Duker AA, 2008. Spatial and demographic patterns of cholera in Ashanti region - Ghana. Int J Health Geogr 7:44.

Państwowy Rejestr Granic (PRG), 2017. Available from: http://www.codgik.gov.pl/index.php/darmowe-dane/prg.html Accessed: May 2017.

Ross M, Langer AM, Nord GL, Nolan RP, Lee RJ, Van Orden D, Addison J, 2008. The mineral nature of asbestos. Regul Toxicol Pharmacol 52:26-30.

Saib M, Caudeville JS, Carre F, Ganry O, Trugeon A, Cicolella A, 2014. Spatial Relationship Quantification between Environmental. Socioeconomic and Health Data at Different Geographic Levels. Int J Environ Res Public Health 11:376586.

Singh PS, Chutia D, Sudhakar S, 2012. Development of a Web Based GIS Application for Spatial Natural Resources
Information System Using Effective Open Source Software and Standards. J Geogr Information System 4:261-6.

Świątkowska B, 2009. Carcinogenic effects of environmental exposure to asbestos - an epidemiological review. Problemy Higieny i Epidemiologii 90:299-305.

Szeszenia-Dąbrowska N, Sobala W, 2008. Zanieczyszczenie środowiska azbestem. Skutki zdrowotne. Raport z badań. IMP: Łódź.

Szeszenia-Dąbrowska N, Sobala W, 2010. Zanieczyszczenie środowiska azbestem. Skutki zdrowotne. Raport z badań - II wydanie poprawione i uzupełnione. IMP: Łódź. pp 157.

Szeszenia-Dąbrowska N, Świątkowska B, 2016. Azbest w Polsce. Zanieczyszczenie środowiska, skutki zdrowotne, zasady bezpiecznego postepowania $\mathrm{z}$ azbestem. Łódź: IMP.

Szeszenia-Dabrowska N, Szymczak W, Wilczyńska U, 1996. Wystepowanie międzybłoniaka opłucnej w Polsce w latach 1980-1993. Przegląd Epidemiologiczny 50:4

Szubert Z, Stankiewicz-Choroszucha B, Wrońska-Sobolewska M, Cwynar E, Dobrowolska J, Wróbel R, Ratka M, Jakubowski J, Skórska-Ciszewska I, Turbańska R, Gazda U, Sova M, Pawłowska-Kozieł H, Latała-Łoś E, Komorowska E, Sobala W, Świątkowska B, Szeszenia-Dąbrowska N, 2011. Realizacja programu badań profilaktycznych pracowników byłych zakładów przetwórstwa azbestu "Amiantus". Medycyna Pracy 62:465-72.

Thompson S, Mason E, 2002. Asbestos: Mineral and fibers. Chem Health Safety 9:21-3.

Virta RL, 2003. Asbestos: Geology, Mineralogy, Mining, and Uses, U.S. Department of the Interior, U.S. Geological Survey, Open-File Report 02-149. Available from: http://minerals.usgs.gov/minerals/pubs/commodity/asbestos/

Wakefield J, 2007. Disease mapping and spatial regression with count data. Biostatistics 8:158-83.

Wilk E, Krówczyńska M, Pabjanek P, Mędrzycki P, 2017. Estimation of the amount of asbestos-cement roofing in Poland. Waste Manag Res 35:491-9.

Wilk E, Krówczyńska M, Zagajewski B, 2014. Asbestos manufacturing plants in Poland. Misc Geogr - Reg Stud Devel 18:538.

Wojciechowska U, Didkowska J, 2016. Zachorowania i zgony na nowotwory złośliwe w Polsce. Krajowy Rejestr Nowotworów, Centrum Onkologii - Instytut im. Marii Skłodowskiej-Curie. Available from: http://onkologia.org.pl/raporty/ Accessed: November 2016.

World Health Organization (WHO), 2015. Available from: http://www.who.int/news-room/fact-sheets/detail/asbestoselimination-of-asbestos-related-diseases

World Health Organisation and International Labour Organisation, 2007. Outline for the Development of National Programmes for Elimination of Asbestos-Related Diseases. Available from: http://www.who.int/occupational_health/publications/Out_NP EAD_ENG.pdf Accessed: January 2014. 